\title{
Optimising learning opportunities for students in complementary classroom and museum settings.
}

\author{
N. Ziebell ${ }^{\mathrm{a}}$ and L. Suda ${ }^{\mathrm{b}}$ \\ aMelbourne Graduate School of Education, University of Melbourne, Victoria, \\ Australia, bMelbourne Museum, Victoria, Australia,
}

\section{Authors:}

Dr Natasha Ziebell

University of Melbourne

Melbourne Graduate School of Education

234 Queensberry St, Parkville, 3010

ziebelln@unimelb.edu.au

ORCiD: https://orcid.org/0000-0002-4706-9836

Twitter: @NatashaZiebell

Linkedin: https://www.linkedin.com/in/natasha-ziebell-1623096a/?originalSubdomain=au

Dr Liz Suda

Melbourne Museum

11 Nicholson St, Carlton 3053

esuda@musuem.vic.gov.au

Twitter: @lizmvhums

\section{Grants:}

This work was supported by McCoy Grants.

This is the author manuscript accepted for publication and has undergone full peer review but has not been through the copyediting, typesetting, pagination and proofreading process, which may lead to differences between this version and the Version of Record. Please cite this article as doi: 10.1002/CURJ.19

This article is protected by copyright. All rights reserved 


\section{Acknowledgements:}

This project was approved by the Department of Education and Training, Victoria.

\section{Disclosure statement:}

No potential conflict of interest was reported by the authors

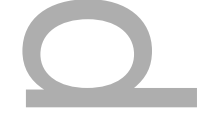

\section{Biographical notes:}

\section{Natasha Ziebell}

Natasha has worked in initial and in-service teacher education programs at the Melbourne Graduate School of Education for the past 12 years. Prior to this, Natasha worked as a teacher in Early Childhood Education and Primary Schools. Her research focuses on collaborative practice, curricular alignment and curriculum authorship, with a particular focus on the intended, enacted and assessed curriculum.

\section{Liz Suda}

Liz has worked as an education consultant in exhibition development projects and created learning programs for school age, university students, teachers and family groups, facilitating museum activities that provide access to the collections, resources and exhibitions at Melbourne Museum for the past ten years. Prior to this she worked in a range of education settings, including secondary, adult and tertiary as a teacher and researcher.

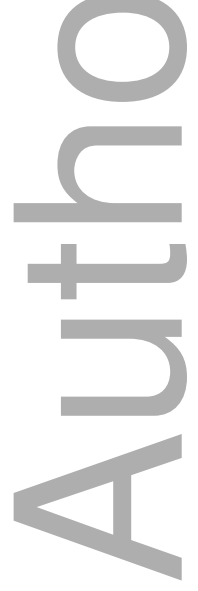


Article type : Original Article

\title{
Optimising learning opportunities for students in complementary classroom and museum settings.
}

\begin{abstract}
The purpose of this project was to create a unique educational experience in order to understand the extent to which excursions can be used to complement and extend classroom-based curricula. The project facilitated a genuine schoolmuseum-university partnership to plan and implement curriculum that supports learning before, during and after museum experiences. A key focus was on developing strategies and designing curriculum that enhanced students' learning of key knowledge and skills through targeted classroom teaching and museum experiences. The findings provide insights into teachers' and learners' perspectives leading to considerations for strengthening collaborative practice. The outcome is a set of principles for planning optimal integration of classroom and museum experiences.
\end{abstract}

Keywords: Curriculum development, learning, planning, pedagogy, museums, excursions

\section{Introduction}

The importance of museums as significant educational venues has been well-documented (Falk \& Dierking, 2018; Kelly, 2011). There are currently over 100 accredited museums in Victoria that provide a broad range of educational opportunities for schools. The Melbourne Museum is a history, culture and science museum, the largest of its kind in the Southern Hemisphere with over 1.19 million visitors in 2018, and a collection of over 17 million items (MV, 2018). The project reported in this paper provides an example of a genuine schoolmuseum-university partnership, which involved a researcher from the University of Melbourne and a museum educator/researcher working with an inner-city primary school to 
plan a unit of work that connected learning experiences before, during and after museum excursions. The key aim of the project was to explore the use of strategies designed to support students' development of knowledge and skills through targeted classroom teaching and museum experiences. This was the focus of the curriculum conceptualisation, design and implementation plan. Consequently, the findings of the research project reported in this paper have a strong focus on teachers' and students' perspectives.

\section{Student learning}

Factors that impact on student learning in museum contexts include 'the nature and degree of structure of the trip; the use of pre- and post-visit materials; students' prior knowledge; the novelty of the setting;... and the social context of a museum visit' (DeWitt and Hohenstein (2011), p. 41). The focus on student learning can be on cognitive outcomes; however, it is also acknowledged that learning in complex museum settings can be more broadly applied to 'any combination of cognitive, affective or social' outcomes (Bamberger \& Tal, 2008, p. 275). The importance of affective engagement for optimising learning and inspiring curiosity is noted as an essential consideration and justification for taking students into museum environments (DeWitt and Hohenstein, 2010; Anderson, Lucas and Ginns, 1999; Falk \& Dierking, 2018). It is interesting to note, however, that some students can also perceive the excursion as a social experience, rather than a learning opportunity by not distinguishing between 'enjoyment' of the experience and 'educational value' (Birney, 1998). A remarkable finding that Falk and Dierking (1997) point to is that irrespective of the intended purpose and outcome of the excursion, beyond the school years, excursion experiences can have a memorable and lasting impact as adults' memories of their primary school excursions are recalled many years after the actual trip (Falk \& Dierking, 1997). Bamberger and Tal (2018) also found that the social interactions in particular were one of the 'long-term impacts of visits' (p. 281).

Schools and teachers invest significant time when organising an excursion to a museum, involving tasks such as scheduling, transport, permissions, managing bookings, safety and budgeting. Excursion experiences are often seen as valued educational opportunities that cannot be replicated in a classroom context. Likewise, museums invest substantial resources in providing education programs for schools(Hackett, 2016; Museums Victoria, 2019). Anderson et al. (1999) report that prior knowledge is vital for optimising learning when going to an excursion venue and that not following up a visit by connecting it to classroom practice 
is a missed opportunity for building conceptual knowledge. The research literature does report the significance of the classroom and museum experiences as being mutually complementary and essential for supporting student learning (Cox-Peterson, 1998).

\section{Pedagogy}

Museums have evolved significantly over the past few decades with innovative exhibitions, hands-on experiences and interactive digital experiences to support learning in these contexts. Similarly, the way that students interact with and explore exhibits is also continually changing depending on the design of the physical environment and the tasks that students are assigned in these spaces. Complementary inquiry-based and experiential pedagogies are generally cited in relation to learning in museums. However, these pedagogies can influence the types of interactions students engage in during an excursion. Pedagogies can impact on the capacity for the student to engage in activities such as posing questions, investigating, reasoning, synthesising information and drawing conclusions (Foreman-Peck \& Travers, 2013).

\section{Planning}

The museum excursion cannot be viewed as an isolated educational event in a students' experience. Hein's (2006) model of the 'Complete Experience Cycle' situates the museum experience in the learning context by acknowledging the importance of the preceding and proceeding learning experiences and the ability to apply and transfer this knowledge. The Complete Experience Cycle draws on Dewey's theory of inquiry that situates knowledge and learning within an experience and through interaction with the environment (Dewey, 1938). Hein's (2006) model shows the individual learning experiences within the context of a broader cycle of human experience. The ongoing opportunities for engaging in inquiries and meaning making through experience is central to this model.

Figure 1. An extensive, inclusive museum experience cycle, based on Dewey (Hein, 2006).

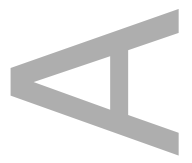

The method for planning excursions to museums is quite significant in terms of the purpose, expected outcomes, and alignment with the content and skills that are being addressed within a broader unit of work. Cooper (2014) states that identifying questions to be investigated 
through sequential learning experiences that build on each other requires careful and considered planning. The museum excursion is 'one experience' within a learning sequence, so the way that it is situated within planning and linked to classroom experiences will determine what the outcomes will be. Effective planning requires teachers to have a sound understanding of what the students will be experiencing while at the museum in order to be able to situate it meaningfully within the unit and lesson sequence. However, other studies have found that the students did compartmentalise classroom and museum experiences and generally did not recognise the links between the two experiences (Anderson, Piscitelli, Weier, Everett \& Taylor, 2002). Therefore, the more explicit the connections are, the more likely students are able to interlink the two experiences (Anderson et al.,2002). Bamberger and Tal (2018) stress the importance of the teacher taking an active 'leader' role while at the museum. This ensures adequate scaffolding of alignment of the pre-, onsite and postexcursion learning experiences. However, in some cases, teachers do not plan any pre- or post-excursion experiences for students, which can negatively impact on their engagement while at the museum and potentially stifle curiosity and learning outcomes (Cox-Peterson, 1998). Noel and Colopy (2012), and Kelly (2011) conclude that increased collaboration between museums and schools could strengthen relationships and support the development of pre- and post-lessons that lead to a stronger alignment of educational goals.

\section{Overview}

The research highlights key affordances and challenges associated with planning a unit of work that links excursion experiences back to the classroom setting. The key focus needs to be on the students, as learners, and maximising the cognitive, social and affective aspects of learning. For teachers and museum educators, the impact of planning learning experiences, effective pedagogies and connecting them to both school and museum contexts remains a challenge. Investigating how designing these experiences can impact on learning can provide further insight into more effective ways of working collaboratively.

The major research question for this study is:

What strategies can be used to support students' learning about key concepts and skills before, during and after visits to the museum?

\section{Materials and Methods}


This study involved a school-museum-university partnership that enabled collaborative planning and resulted in the design of a curriculum unit that was implemented over one term (10 weeks), focusing on the year 5 Economics and Business curriculum learning area. The school used an adapted version of Murdoch's (2015) inquiry-based planner, which includes curriculum links, big ideas, fertile questions, inquiry-based skills, and learning experiences for the inquiry sequencing of 1) Tuning In/Preparing to Find Out, 2) Finding Out, 3) Sorting Out, 4) Going Further, 5) Reflection and 6) Taking Action. The unit had not been taught previously at this year level so it was the ideal opportunity to create a new unit plan and to support the implementation both in the school and museum contexts.

This qualitative case study adopts an interpretivist/constructivist philosophical perspective. Qualitative research methods provide the means to learn about practices in complex settings, which can lead to the development of recommendations that can improve practice (Merriam, 2016). Through empirical inquiry, we sought to understand the complexity, 'uniqueness and commonality' of these contexts when working collaboratively with educators and students (Stake, 1995).

\section{Participants}

The staff from the Melbourne Museum and the University of Melbourne worked with four teachers and a cohort of approximately 100 grade five students (10-11 year olds) from a school in metropolitan Melbourne. The project attempted to replicate 'usual' classroom and excursion experiences as much as possible.

\section{Methods}

Miles and Huberman (1994) state that the strength of qualitative data is that the information is taken within the context of the situation. This is particularly pertinent in school and museum contexts. Data collection was conducted within the natural setting to promote 'richness and holism' that represents the complexity of the situation and enables a thorough and detailed analysis of learning in each setting (Miles \& Huberman, 1994).

\section{Partnership structure}

Prior to the school term commencing, the partnership between the school, museum and university was established. The museum and university educators participated in a 
collaborative team planning session with teachers to design the intended unit. The inquirybased unit of work was entitled, 'The Business of Helping Others'. The focus for the unit was the Business and Economics learning area with a particular focus on the changing nature of work, resource allocation, producers and consumers, and enterprise and entrepreneurship. The teachers were ultimately responsible for unit planning decisions and the enacted curriculum, which differed slightly between classes depending on the teachers' knowledge of the students in their class and the direction of their inquiries. Museum and university educators were involved by conducting learning experiences in both the classroom and the museum contexts, and by providing resources such as additional videos and reading materials. The museum and university researchers conducted a pre-excursion lesson in the school setting that focused on source analysis in preparation for visiting the museum. The teachers also conducted pre-excursion lessons with their classes before attending the museum.

The galleries that were visited during the first excursion experience were:

- The Forest Gallery and Milarri Garden living galleries that contain ancient, new and rare Australian specimens.

- The First Peoples, Bunjilaka Gallery focuses on the diverse Countries, history and cultures of Aboriginal peoples in Victoria.

- Melbourne Story and Making a Quid examining stories and artefacts that communicate how Melburnians have lived and worked in the past and to the present.

The first excursion focused on the concept of resources, so the students participated in a program led by the university researcher in the living Forest Gallery and Milarri Garden to explore how we use resources from the environment. Understandings related to the concepts of resources, supply, demand, consumption and production were extended during the World Trade Game conducted in the classroom setting after the excursion with the university researcher. Students also participated in a museum staff-led program, 'Making a Quid', that focused on the changing nature of work over time. Two museum educators led the programs for different groups of students. A teacher-led trail focusing on indigenous perspectives on work and resources were examined in the First Peoples gallery.

As the unit progressed, the focus changed from the nature of work to business and enterprise, culminating in the students creating their own businesses towards the end of the unit. During 
the second excursion, students explored the museum as a business. The focus included different jobs undertaken by staff at the museum (gallery designers, curators, volunteers etc.). Students had an opportunity to pose questions about roles at the museum in an interactive session involving a panel of six museum staff that was led by the museum educator/researcher. Following on from pre-excursion activities conducted by the teachers that related to marketing, the students were shown examples of museum marketing before using digital technology to record their own television advertisements in the galleries to promote the museum. The students applied these skills again in their school setting when creating a marketing campaign for their businesses. During the second excursion, in addition to the galleries used in excursion 1, students also visited the Children's Gallery, Science and Life Gallery (Dinosaur Walk, Wild, Bugs Alive and 600 Million Years) to create their advertising campaign for the museum. The exhibitions at the Melbourne Museum are handson, dynamic and interactive.

Table 1 shows the timeline, the context in which the learning experiences were undertaken and a summary of the data that was analysed for this project. The balance between teacherdirected and student-led activities was an important design feature of the unit. In this particular museum setting, both types of activities are supported with resources for teachers, so this data provided some insight into the benefits and challenges of these approaches. The museum programs were tailored specifically to meet the goals of the unit and pre and postexcursion activities were designed in a way that aligned content knowledge and skills across both settings. There were additional activities planned for the unit that the teachers conducted in the school setting. A record of these activities was outlined in the unit planner and collected by scanning the students' workbooks at the end of the unit.

Table 1. Data summary and activities.

\section{Data Analysis}

The case study design is characterised by a single-case that contains embedded units of analysis. For the purposes of this study, the 'case' consisted of the year 5 level at a government school located in the inner northern region of the greater metropolitan area Melbourne, Australia. The analysis was conducted using an 'inductive investigative strategy' (Merriam, 2016). A summary of the units of analysis is presented below in figure 2. 
Figure 2. Case study design. Adapted for this study from Yin (2009) p. 46.

The analytic phase of the project involved the systematic process of compiling data, disassembling the data through coding and reassembling the data to identify emerging patterns (Yin, 2011). Inductive analyses were conducted by the university researcher and a research assistant using Computer Assisted Qualitative Data Analysis Software. StudioCode was initially used for audio recordings. Qualitative data analyses of documents were conducted using NVivo. Inductive analysis was used to generate coding schemes for planning documents, semi-structured interviews, transcripts of audio-recordings and work samples. A sample coding scheme developed as a result of the inductive analysis conducted for the teacher interviews.

\section{Results}

The following results provide an insight into a selection of learning experiences throughout the unit and are presented with a focus primarily on students' and teachers' perspectives. The students were particularly enthusiastic about participating in this project and their attitude towards working with educators from the museum and university was quite positive. Overall, the teachers noted the significance of the museum as a valued educational and cultural institution that provided a unique learning environment for students.

All the exhibits and that, that hands-on stuff. We can't have all the artefacts and the visuals and all that here at school. We could watch it on a video, it's not the same... Actually being in a focused exhibit that's focused on something and all the information is about that. Like they can get so much just from that 30 square foot exhibit that might take you weeks and weeks to do at school because it's so intense. (Sarah)

Sarah points to the conceptual and experiential density of museum exhibitions as a way of articulating the uniqueness of the museum experience. This type of experience is not replicable in the classroom, even with the use of multimedia, but it is an experience that can complement learning in the classroom context.

\section{Teachers' reflection on essential content}


The link to the museum had two different foci. During the first excursion visit, students engaged in experiences that focused on the nature of work from a historical perspective, environmental resources that we use and indigenous perspectives related to resources and work. The second excursion focused on two key ideas: the museum as a business; and, marketing the museum. The teachers were prompted to reflect on the key content and skills that were addressed for the unit of work undertaken during the whole term. The following interview excerpts show that teachers identified some complex concepts related to business and economics as valued outcomes for students:

I think it was to have an understanding of the significance of labour. The history of labour but also labour in the world today. What it takes in terms of human energy, human output to have the world function in the way that it does today. Especially for these kids that are so privileged and benefit from all of this human labour. I think that was an important part for me, for them to understand...I think the social and historical aspect was really important for me for them to understand. (Alicia)

I would say the key learning outcomes are they understand how a business works and the different things you need to set up a business and what a business needs to do to sustain its practice with the marketing and the advertising and just being able to get the resources organised... Themselves as consumers is another thing. They're much more aware of what influences their choices and how they can influence other people in their choices, (Sarah)

The museum is not usually the first choice of excursion venue for a Business and Economics unit. However, the nature of the venue and the fact that the Museum is a business did provide multiple entry points for authentic engagement with the key concepts related to this learning area. The museum also afforded opportunities to look at the changing nature of work by integrating historical perspectives. By developing their marketing videos in a real-world setting students were able to test their knowledge and understanding of the concept of marketing in a business setting.

\section{Students' reflection on their learning}


The student reflections showed that there is a diverse range of responses to the learning experiences and their views on which activities helped them learn. Figure 3 shows the responses to the survey question: How much did the following experiences help you learn?

Figure 3. Students' survey responses.

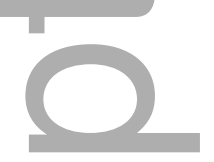

The data shows that all students identified different experiences that helped them learn. For example, some students reflected that they had learned a lot in the Forest Gallery and wanted to learn more about plants as resources, even though this was the activity that had the lowest score for 'I learnt a lot'. Some students did not find the Forest Gallery at all useful to their learning. As a result, the broad range of experiences did reflect the diverse interests of the student cohort in different ways depending on their area of interest and their connection to the gallery. Learning about the overarching economics concepts was possible by engaging in a range of experiences and activities. However, it is important to note that the scope of activities offered ensured that there was something that every child can engage with to some degree. This finding is further confirmed in the survey section where students were asked to identify what they would like to learn more about. The responses ranged from 'I can't think of anything because I learnt everything' to the 'Forest Gallery', 'World Trade', 'Advertising', 'Businesses' and 'How to make money'. Some students also wanted to learn more about jobs in the museum. The fact that students had visited the museum had also sparked their interest and curiosity in other areas that were unrelated to the content addressed in the unit, such as Dinosaurs and Ancient Rome. While it can be argued that there are significant opportunities to explore the ancient Roman economy, the museum does not have an Ancient Rome exhibition and this content is not addressed until the year 7 curriculum. These comments show an interest in historical content beyond that which is mandated at this year level.

In response to the most interesting thing that students felt they had learned about during the unit, students identified the whole range of activities. However, when responding to what they were proud of, most students identified the 'World Trade Game', which is also consistent with the responses in the graph in figure 3. Simulations place the students within a scenario where they are required to predict outcomes, make decisions and take action based on the available information at the time. In this case, students were members of one of four 
countries, Alpha, Beta, Gamma and Delta, and took on roles such as treasurer, trader and bidder. The countries were required to manage income and expenditure while operating within a fickle market and in an environment where resources were not distributed equally. The key to the success of the country relied on trading, developing alliances with other countries and considering opportunity costs. The students had to make decisions about paying themselves a wage that related to a standard of living index. The use of simulations as a pedagogical approach in both classroom and museum contexts is an area that could be further explored. The teachers also reflected on the use of simulation as a teaching strategy:

The other thing, the World Trade game ... the bracelet making game. That was fantastic. The kids still talk about that. They are like, "Are we going to do that again?" That was a really great way of teaching them so many little things in such a short time. Because you can talk all about the unfairness of business practices. But when they actually experience it, it really clicks in. That was another good one. (Melissa)

Definitely when we did the World Trade simulation game. That was fantastic and one of the reasons I think I really loved that was because I saw a different side to a lot of students during that activity. A lot of kids that are quite resistant to work in general really flourished in that set up. That was fantastic, I loved that. It was a highlight for the kids as well. (Alice)

\section{Developing source analysis skills}

During the first pre-excursion visit to the school, the aim for the 'small object, big story' activity was to focus on objects and introduce source analysis skills. The rationale and structure of this learning experience have been previously reported in (Ziebell \& Suda, 2019). The objects that were modelled included a plate and 'baskets'. This was chosen specifically knowing that students would be likely to walk past these items in a glass case at the museum. This activity highlighted the significance of artefacts that have been chosen for display and the stories associated with them. The students were asked to bring in a personal item that had special significance to them and a peer completed a source analysis task related to it.

I think that was a big thing because that really made the kids understand what an artefact is and what the museum actually displays and how they pick what's 
important, and how what's important to one person might not be as important to different people or different cultures or whatever. (Sarah)

Whilst content knowledge was an essential part of the unit, the skills for learning how to engage with museum artefacts also served as an impetus for eliciting questions and engaging in critical thinking.

They've been taken to these museums all over the world, but that doesn't mean that they've connected with museums all around the world. You'll often see them glaze over. That's why it's really nice to have some of the activities that we were doing at the museums where they were creating the advertisement or whatever. When there was something to hook them in ... that's why when you were talking about those grass trees was so valuable to those kids and became such a highlight for so many of them because suddenly this thing they had walked past 20, 30 times before had this wealth of meaning and significance. (Alicia)

\section{Additional knowledge and skills}

In addition to key curriculum content that needed to be addressed, the teachers also made links to other skills that related to the Curriculum Capabilities demonstrating the complexity of inquiry-based learning and the integrated curriculum. Alongside key content from the learning areas of Economics and History, integration across domains such as mathematics, critical and creative thinking and interpersonal learning was also a priority for teachers:

Then in terms of skills, it was obviously all the critical and creative thinking skills to be able to dig and question and deepen curiosity. And then also the skills around managing a financial plan, or I guess that's more maths. But still planning and understanding all the elements that are required in order to set up a small business, in the most basic sense. (Alicia)

I think the World Trade game was really good for their teamwork skills and so was the filming of the ad actually. Teamwork and negotiation and that sort of ... That's been probably really good during this unit. The other skills, obviously, the academic stuff that they've learned through doing this. The critical thinking skills I think are really good especially when it comes to marketing because...critical thinking is a big thing for me. (Melissa) 
The analysis of the transcripts did show that links between the classroom and the museum were made by the teachers and the students:

Making a quid, that's right. I think that was a really good outcome for the kids. I think once they came back from that they were interested in the history of work. And we did actually do a couple of things in this class about the history of work at a manor in Melbourne which they followed on from that. So that was a good outcome. I thought maybe the history of making a quid was a good outcome. (Anthony)

They were thinking with a lot more depth and breadth, which I was surprised by the change in some of the students when you get some of those hands-on activities like the World Trade simulation game. Some of my kids were transformed in that environment and that was really wonderful to see. (Alicia)

While links were beginning to emerge and did encourage curiosity, further research is required to strengthen complementary learning experiences in both settings. The extent to which links are made in both settings needs to be articulated more explicitly in both planning documents and in communication with students. Metacognitive activities that require students to actively reflect on connections between different activities might also assist in determining how these connections are made by students.

\section{Linking excursions, support and planning curriculum (working with the museum)}

The interview protocol was designed to elicit the teacher's perspectives on planning excursions to the museum, the use and availability of resources, strengthening partnerships and impact on student learning. The following section contains a summary of several key considerations, issues and recommendations that teachers raised concerning museum excursion experiences.

\section{Teacher visits prior to the excursion}

The teachers reflected on what essential knowledge was required for teachers to understand before visiting the museum. The responses highlighted the importance of teacher visits prior to the excursion so that they could become familiar with the venue, galleries, programs and 
specific artefacts. This was seen as essential for enabling teachers to support students during the excursion by directing them to certain areas or highlighting important information.

To be honest I think if you're going to the museum and you hadn't been there before I think the kids would get less out of it. I reckon it's really helpful to already know what the museum's all about. I mean I know I hadn't done the making a quid thing but I've been to pretty much everything else and because I was already ... I'd seen it and kind of knew what was going on. There wasn't that feeling of like, "Oh God where do we go next?" And, "How do we get out of here?". (Anthony)

Consideration does need to be given to teachers' pedagogical approaches and the extent to which these are in harmony with the museum experience. Programs at the Melbourne Museum are generally booked for one hour, but there are so many learning opportunities that could be maximised during the entire excursion experience that do not need to be led by museum educators. Further research might explore the efficacy of a more focused and dense approach by teachers while guiding their students through the museum. How might the teacher optimise opportunities for learning and reflection? How might one measure the impact of seemingly 'non-productive' interactions and unplanned experiences in the museum setting?

\section{Accessing online material}

In addition to the physical space in museums, the extensive virtual collections, tours and supplementary information online provide another avenue for teachers to access valuable resources. However, a key issue is accessing this information. During the interviews, the teachers seemed unsure as to whether these resources already existed online or stated that they simply did not have the time to access the museum website during unit planning. Teachers were interested in accessing short educational videos related to their focus of inquiry as well as online resources available on Collections, but they were not really sure of what the museum offers. This possibly suggests a challenge for web designers in devising search and navigation systems that are easy to follow. Teachers stated that email was the preferred method of communication with the museum. Ironically, the strike rate of teachers who open regular monthly newsletters from MV Teachers that does contain such information is very low. 


\section{Pre- and post-excursion activities}

As outlined in the literature review, the importance of linking classroom and museum experiences has been well-documented. Teachers were interested in using supporting materials and ideas for pre- and post-excursion activities such as videos, articles and learning experiences that were associated with the excursion. Again, there was some uncertainty about the availability of resources online: 'I don't know what's already up there' (Melissa).

Museums have extensive resources available to teachers online; however, the practicalities surrounding access and implementation of materials are not always convenient for teachers. Essentially, this is an issue related to accessibility of materials and the time teachers have to conduct research in their planning.

\section{Artefact accessibility}

Information, research and learning experiences regarding particularly significant artefacts that can be investigated prior to coming into the museum was suggested for creating strong links back to the classroom. The development of such resources could support understanding the significance of the object that might not always be readily visible in the museum gallery.

It's probably hard because I'm sure the curators have done their job and they think every single thing they have put in there is super important. And, it is in that way. But, perhaps having like, I don't know if this comes out right, but the big ticket items in each area...The teachers can do that before they come and maybe direct the kids there when they're in the area or whatever. Be like, "Oh, have you seen this thing. It's really cool." Even like a little walk through for teachers or something or a video that you can show your kids before you go. (Melissa)

One of the pre-excursion activities involved students watching a short film prior to the first excursion visit:

They were helpful in terms of when we got to them because we'd already watched that, when we got to the museum and they had the big model and stuff, the kids were like, "Oh, yeah, this is like, links into what we've seen". And I feel like they got a lot more out of that than if they'd just seen it there 
without the prior learning and the prior knowledge. That was quite helpful in that way (Sarah).

Supplementary excursion resources that support deep knowledge of significant artefacts prior to attending the museum provides a strong link back to the curriculum focus within which the excursion is situated in.

\section{Preparation and organisation}

Finally, the teachers also noted the importance of having access to maps and some further practical information about where bags can be stored and areas where students can eat their lunch. Museum Bookings staff send such information in a confirmation email to the person who has made the booking. This email includes the program/spaces booked for the day and information on bags, lunch and forth. However, it is unclear where the breakdown in communication occurs.

\section{Student Perspectives: Post Unit Reflections.}

At the conclusion of the unit, the students reflected on their experiences via a survey. The questions related to the most memorable experiences that students had, what they had learned, any advice they had for teachers and advice they would like to offer the museum. The comments are collated in figure 4 below using the key themes that emerged from the data.

Figure 4. Student reflections and advice for teachers and the museum (verbatim).

The student surveys highlighted the nature of learning at the museum and how students perceive the experience. What are their expectations of learning in these contexts? The students' comments relating to 'fun' show the extent to which affective learning plays a part in students' overall engagement and curiosity. It is also evident that students expect to learn something as a result of the excursion experience, but they also value activities that they find interesting. The affective outcomes and their impact in relation to student engagement and learning cannot be understated in this context. 
When given worksheets, students work towards completing tasks for the sake of 'completing tasks'. Some students felt pressure to finish the tasks as this is what they were used to in school. The use of worksheets when in museum environments does need to be carefully considered in relation to their usefulness, the key areas that the worksheet will direct students to particular exhibits and the extent to which they limit engagement with the physical environment. Therefore, consideration needs to be given to taking school-based pedagogies into informal, dynamic and hands-on learning environments.

The results provide an overview of several factors that impact on students' experiences at the museum. Overall, both teachers and students commented on the significance of the Melbourne Museum as an enjoyable and important educational excursion venue. The learning experiences afforded by the educational programs and the design of exhibitions can be optimised through careful and targeted planning of pre-, during and post-excursion experiences and pedagogical approaches. This is contingent on there being a clear purpose for the visit within the context of a broader learning sequence.

\section{Discussion}

This project attempted to integrate the museum excursion experience more closely with the classroom curriculum. It is acknowledged that museum educators cannot work in this way with all schools that attend the venue. Nevertheless, the findings do provide some insights into possible ways of strengthening collaboration with schools and working together with teachers to design curriculum. One of the challenges was finding the time for educators to meet and for students to engage in sustained learning sequences during what was a considerably busy school term. During this project, teachers were required to implement the National Assessment Program: Literacy and Numeracy (NAPLAN) and write semester 1 reports for their students. The teachers' enthusiasm, passion and capacity for engaging in this project during a very busy term was incredibly inspirational. The following recommendations are based on the data generated for this project and represent teachers' and students' perspectives. This provides a summary of considerations for curriculum alignment across school and museum settings and suggests possible targets for future interventions:

Connecting Excursion Experiences and School-based Learning through Curriculum Design 
1) The excursion experience is situated within a sequence of learning that connects the museum experience explicitly with classroom-based instruction and curricular goals.

2) Key concepts and skills are taught, practised and reinforced through targeted learning experiences in both classroom and museum contexts.

3) Post-excursion activities incorporate the use of information generated during the excursion for deeper learning, to draw conclusions and to reflect on the learning experience.

4) Plan opportunities for students to pose, explore and respond to questions before, during and after the excursion experience.

5) Optimise learning through designing formal and informal learning experiences while at the museum, beyond the programs that the museum educators offer.

\section{Optimising Student Learning and Engagement}

6) Make museum practices visible to students. For example, how are artefacts selected or how are galleries designed? This information should be transferable to other contexts.

7) Create a diverse range of formal and informal experiences are planned that accommodate students' interests and inspire curiosity.

8) Use pedagogical approaches that foster a range of interaction types between students, educators, environment and technology (including simulations and inquiry-based approaches).

9) Provide opportunities for students to work in various ways (independently, pair work or in groups). The social context impacts on student experience.

\section{Resources for Teaching}

10) Resources to support planning are accessible to teachers online and are communicated clearly at the booking stage.

11) Professional learning for teachers is easily accessible and enhances skills, knowledge and confidence when using the museum as an educational resource. 
Andre, Durkson \& Volman. (2017) state that 'we know very little about children's learning processes and results from experiences in different museum types, and how their learning can be best guided' (p.48). Further research is required that focuses on how learning is linked to pre and post-excursion learning experiences and more broadly, within the context of a unit of work. Strategies for aligning knowledge and skills between the school and museum contexts, and transferability needs to be investigated further. One of the conclusions, that verifies the Anderson et al. (2002) findings, is the diversity in students' interests and what they thought was particularly memorable when reflecting on their museum experiences. The affective elements of their learning are difficult to quantify. For example, an effusive 'That was really cool!' does not necessarily reveal the breadth of the learning. Similarly, teachers' observations and reflections do not necessarily explain what and how students are learning. Incorporating students' voice, interest and curiosity can be accommodated in the planning stages of a unit to enable a metacognitive approach in the planning, delivery and evaluation of a unit of work. The findings show that there is no singular approach to effective practice, but a broader range of learning experience does have the potential to target a broad range of skills and content knowledge. The range of learning experiences offered will also impact on student engagement and affective outcomes. Museums strive to offer a memorable educational experience for all visitors. This study acknowledges teachers and museum educators as speeialists in their respective fields. Pedagogical approaches in formal and informal learning contexts can be strengthened in complementary classroom and museum settings. Given an opportunity for further effective collaborative practice, educators have the potential to foster cognitive, affective and social learning experiences for learners in both contexts.

\section{Acknowledgements}

This project received funding from McCoy Fund, and was approved by the University of Melbourne, Melbourne Museum and the Department for Education and Training.

\section{References}

Andre, L. Durkson, T., \& Volman, M.L. (2017). Museums as avenues of learning for children: A decade of research. Learning Environments Research, 20, 47-76. 
Anderson, D., Lucas, K., Ginns, I., \& Dierking, L. (1999). Development of knowledge about electricity and magnetism during a visit to a science museum and related post-visit activities. Science Education, 84(5), 658-679.

Anderson, D., Piscitelli, B., Weier, K., Everett, M., \& Tayler, C. (2002), Children's museum experiences: Identifying powerful mediators of learning. Curator: The Museum Journal, $45,213-231$

Bamberger, Y., \& Tal, T. (2008). Multiple outcomes of class visits to natural history museums: The students' view. Journal of Science Education and Technology, 17(3), 274-284.

Birney, B. A. (1998). Criteria for successful museum and school visits. Curator: The Museum Journal, 31, 292-316.

Cooper, H. (2014). Why Are There No History Text Books in English Primary Schools? ENSAYOS, Revista de la Facultad de Educación de Albacete, (29)1, 27-42.

Cox-Peterson, A., \& Pfaffinger, J. (1998). Teacher preparation and teacher-student interactions at a discovery center of natural history. Journal of Elementary Science Education, 10(2), 2035.

Dewey, J. (1938). Logic, the theory of inquiry. New York: Henry Holt and Company Inc.

DeWitt, J., \& Hohenstein, J. (2010) Supporting Student Learning: A Comparison of Student Discussion in Museums and Classrooms. Visitor Studies, 13(1), 41-66.

Falk, J. H., \& Dierking, L. D. (1997). School Field Trips: Assessing Their Long-Term Impact. Curator, (3), 211-218.

Falk, J. H., \& Dierking, L. D. (2018). Learning from museums. Maryland US: Rowman and Littlefield.

Foreman-Peck, L., \& Travers, K (2013) What is distinctive about museum pedagogy and how can museums best support learning in schools? An action research inquiry into the practice of three regional museums. Educational Action Research, 21(1), 28-41. 
Hackett, A. (2016). Research methods for exploring children's experiences of museums. Retrieved from https://abigailhackett.wordpress.com/2016/06/05/research-methods-forexploring-childrens-experiences-of-museums/

Hein, G. (2006). John Dewey’s “wholly original philosophy” and its significance for museums. Curator, $49(2), 181-203$

Kelly, L. (2011). Student learning in museums: What do we know? Report prepared for the Sovereign Hill Museums Association.

Merriam, S. B., \& Tisdell, E. J. (2016). Qualitative research: A guide to design and implementation. San Francisco: Jossey-Bass.

Murdoch, K. (2015). The power of inquiry. Northcote, Vic: Seastar Education.

Museums Victoria. (2018). Museums Victoria annual report 2017-2018. Retrieved from https://museumsvictoria.com.au/media/7791/annual_report_2017-2018_3.pdf

Miles \& Huberman. (1994). Qualitative data analysis: An expanded sourcebook. Thousand Oaks, CA: SAGE publications.

Noel, A. M., \& Colopy, M. (2006). Making history field trips meaningful: Teachers' and site educators' perspectives on teaching materials. Theory \& Research in Social Education, 34(4), 553-568.

Stake, R. E. (1995). The art of case study research. Thousand Oaks, CA: SAGE publications.

Yin, R. K. (2009). Case study research design and methods. Thousand Oaks: SAGE publications.

Yin, R. K. (2011). Qualitative research from start to finish. New York: Guilford Press.

Ziebell, N, \& Suda, L. (2019). Treasures from the past: Developing critical thinking in the primary classroom. Agora, 54(1), 20-28. 


\begin{tabular}{|c|c|c|}
\hline Stage & Summary & Data \\
\hline $\begin{array}{l}\text { Term Curriculum } \\
\text { Planning Session } \\
\text { School context }\end{array}$ & $\begin{array}{l}\text { Teaching team (4 teachers) } \\
\text { [name deleted] (Museum) } \\
\text { [name deleted] (University) }\end{array}$ & $\begin{array}{l}\text { 1. Teacher planning } \\
\text { documents. } \\
\text { 2. Student workbook } \\
\text { samples. }\end{array}$ \\
\hline $\begin{array}{l}\text { Week 2: Pre- } \\
\text { excursion lesson } \\
\text { Classroom context }\end{array}$ & $\begin{array}{l}4 \text { x } 50 \text { minute lessons (1 per class). } \\
\text { Source Analysis Skills }\end{array}$ & $\begin{array}{l}\text { 1. Student responses to } \\
\text { 'What is a museum?' } \\
\text { 2. Source analysis } \\
\text { responses. } \\
\text { 3. Student survey }\end{array}$ \\
\hline $\begin{array}{l}\text { Week 3: } \\
\text { Excursion } 1 \\
\text { Museum con }\end{array}$ & $\begin{array}{l}100 \text { students three groups (rotations): } \\
\text { [name deleted] - Making a Quid } \\
\text { (guided session) } \\
\text { [name deleted] - Forest Gallery and } \\
\text { [name deleted] Garden (semi-guided) } \\
\text { First Peoples and Forest Gallery (self- } \\
\text { guided) }\end{array}$ & $\begin{array}{l}\text { 1. Eight students audio- } \\
\text { recorded during excursion } \\
\text { (Two students from each } \\
\text { class). } \\
\text { 2. Museum Trail } \\
\text { Worksheets } \\
\text { 3. Student survey }\end{array}$ \\
\hline $\begin{array}{l}\text { Week 4: World } \\
\text { Trade Game } \\
\text { Classroom context }\end{array}$ & $\begin{array}{l}4 \mathrm{x} 1 \mathrm{hr} 40 \text { lessons } \\
\text { [name deleted] and class teacher }\end{array}$ & 1. Student survey \\
\hline $\begin{array}{l}\text { Week 6: } \\
\text { Excursion } 2 \\
\text { (Museum col }\end{array}$ & $\begin{array}{l}\text { Making an Advertisement } \\
\text { Panel discussion - The museum as a } \\
\text { business } \\
\text { (Museum context) }\end{array}$ & $\begin{array}{l}\text { 1. Eight students audio- } \\
\text { recorded during excursion. } \\
\text { 2. Recorded advertisements } \\
\text { (work samples). } \\
\text { 3. Student survey }\end{array}$ \\
\hline $\begin{array}{l}\text { During unit } \\
\text { implementation }\end{array}$ & Teacher questionnaires & $\begin{array}{l}\text { 1. Survey sent to teachers } \\
\text { every fortnight during unit } \\
\text { implementation. }\end{array}$ \\
\hline $\begin{array}{l}\text { Week 10: Post } \\
\text { unit } \\
\text { implementation }\end{array}$ & Post unit reflections & $\begin{array}{l}\text { 1. Semi-structured teacher } \\
\text { interviews. } \\
\text { 2. Student surveys }\end{array}$ \\
\hline
\end{tabular}




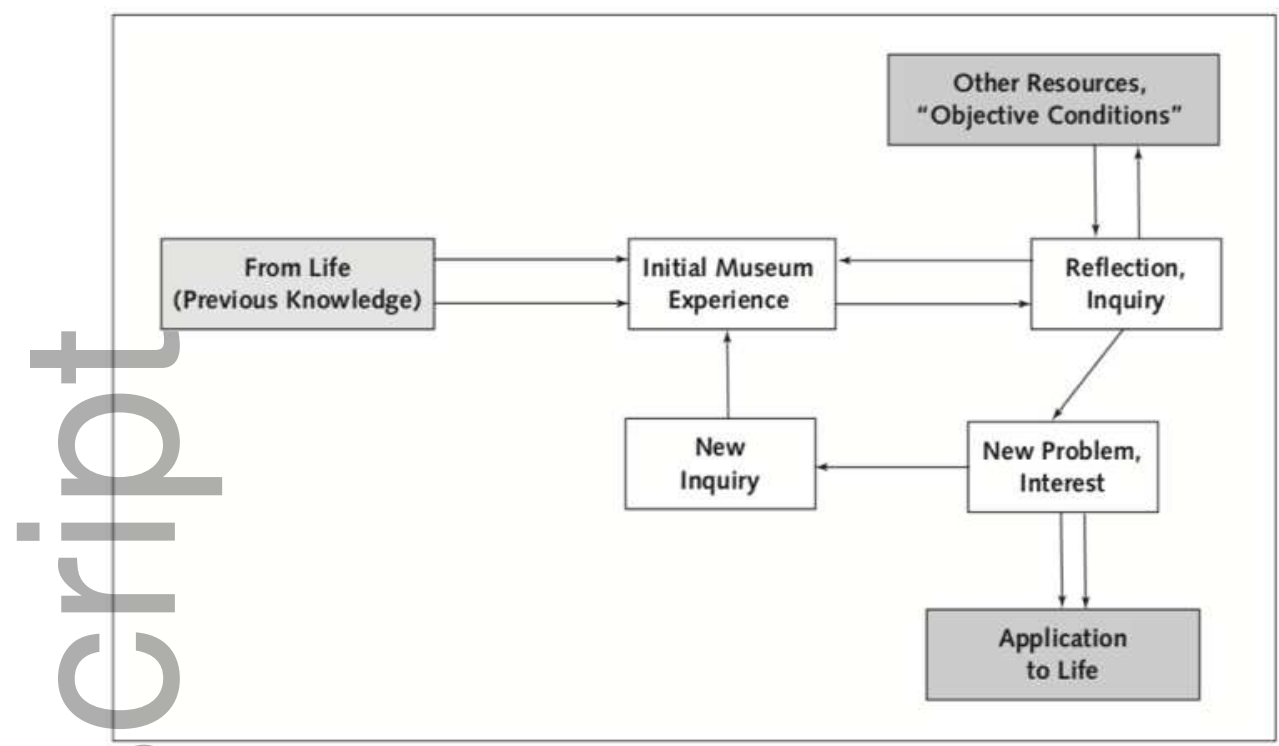

curj_19_f1.png

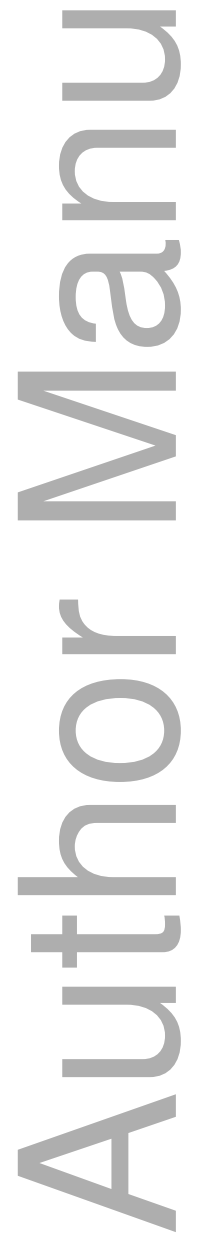




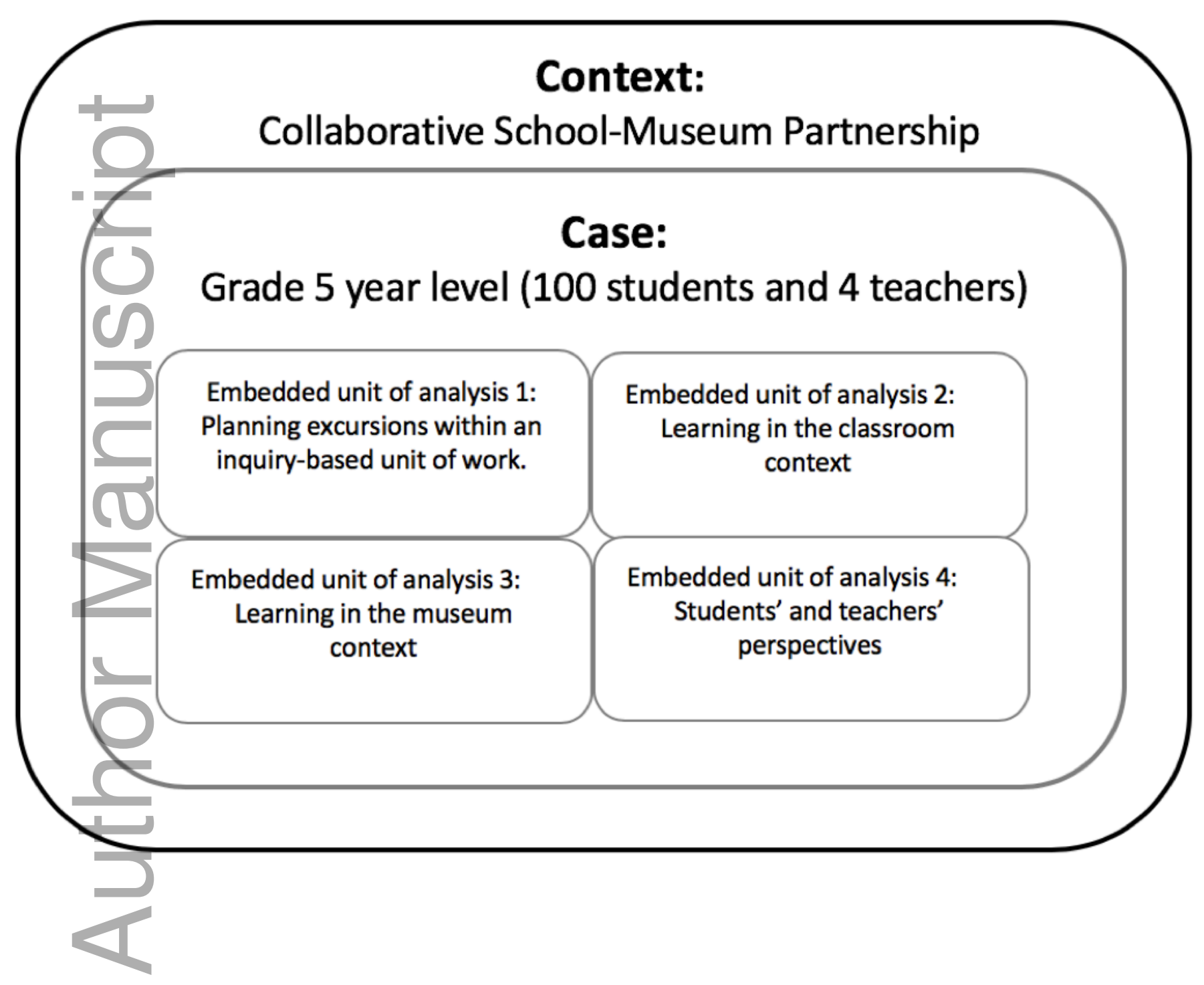

This article is protected by copyright. All rights reserved 


Analysing an object: Source analysis was
modelled in the class using a family heirloom
(plate). Students brought in their own special
items from home that were analysed by peers
(classroom).
Making a Quid: Staff-led experience focusing
on economics and the nature of work from a
historical perspective (museum).
First Peoples: Self-guided experience with an
emphasis on resources and work from an
indigenous perspective (museum).
Milarri Garden: Staff-led experience. Focus on
how Aboriginal peoples used resources for
tools, food, shelter and medicine. Students
identified plants and the purpose for which
they were used. Link to sustainability.
Forest Gallery: Self-guided tour through the
living gallery of new and ancient plants. Focus
on environmental resources (museum).
World Trade Game: Focus on key economic
concepts including trade, supply, demand,
opportunity cost income, expenditure, and
quality of living (classroom)
Making an Advertisement: Students created
an advertisement to increase the number of
visitors to themuseum (museum).
Expert Panel: Museum staff in various roles
questions about their jobs (museum).

questions about their jobs (museum).

\begin{tabular}{l|rrrrr|r}
\hline & & & & & \\
\end{tabular}

curj_19_f3.png 


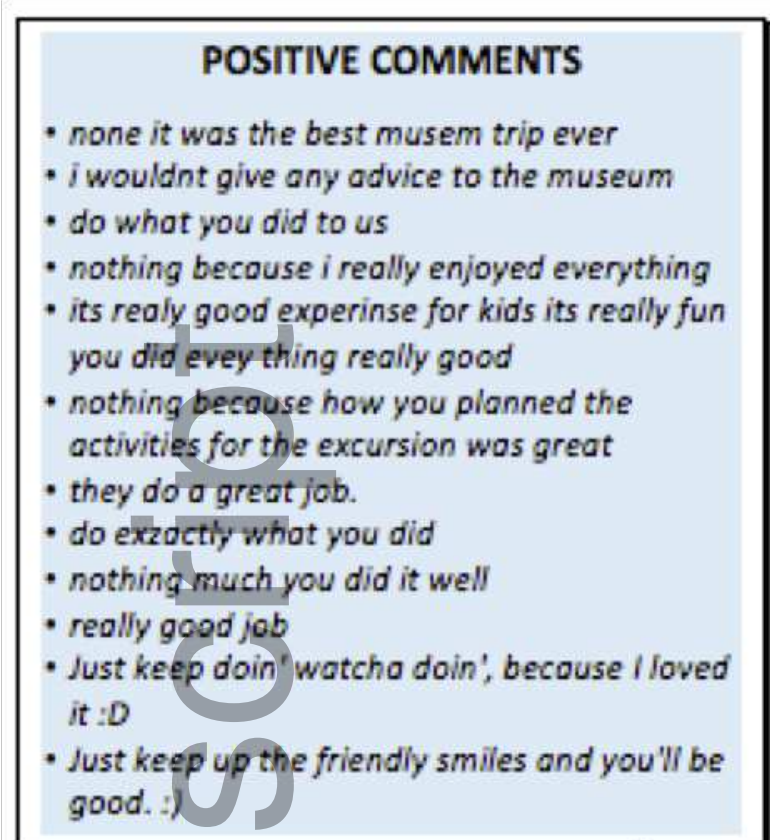

LEARNING EXPERIENCES

- Do not give students sheets while they are expioring, give them a sheet afterward to show what they have learned about a given topic.

- don't make kids stay in the lecture theotre for quite so long oterwise it gets too boring

- To not have us sitting down to long and show us a variety of things

- do a viriaty of things

- open more exbaditions

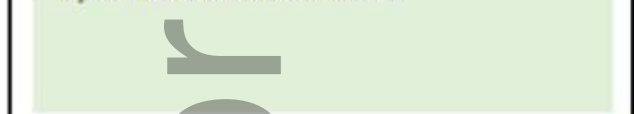

COMMUNICATION
- make it more child friendly
- to speak in a more child friendly way.
- have less questions to answer during the trip
- explain a bit more
- don't spend to long talking and get right into the
activity
- don't use confusing words or speak to quickly
- to listen to what the kids say
- Do things that they have lots of interest in
- To talk more about it and to not make us take notes
- less talking more interactive things
- a bit more patience when children are asking
questions
- Maybe to work more one on one

\section{MAKE IT FUN AND INTERESTING}

- to give them fun activities

- make it fun!

- im not saying it wasnt fun cause it was really fun and intresting but whemn working with children make it a bit more fun and enthusiastic

- make it a bit more fun

- make it more interesting to kids

- make it educational and fun

- make sure you toke them to very exciting stuff as well as learning about history and future

- make the learning fun

- "Make it fun."

\section{INDEPENDENCE}

- we should have a book to go arond on our on and anser qwestions maby more time to look and eat

- Not as much explaining ond let the kids find out their own info.

- Let the kid's go to popular and new exhibitions like the viking exhibition ond Melbourne story (my fovourite) rather than the forest gallery because f thought that was a bit boring

curj_19_f4.png 


\section{University Library}

\section{- M M I N E R VA A gateway to Melbourne's research publications}

Minerva Access is the Institutional Repository of The University of Melbourne

Author/s:

Ziebell, N;Suda, L

Title:

Optimising learning opportunities for students in complementary classroom and museum settings

Date:

2020-01-09

\section{Citation:}

Ziebell, N. \& Suda, L. (2020). Optimising learning opportunities for students in complementary classroom and museum settings. CURRICULUM JOURNAL, 31 (3), pp.539-556. https://doi.org/10.1002/curj.19.

Persistent Link:

http://hdl.handle.net/11343/276286 